L. Barbero · U. A. Glasmacher · C. Villaseca

J. A. López García · C. Martín-Romera

\title{
Long-term thermo-tectonic evolution of the Montes de Toledo area (Central Hercynian Belt, Spain): constraints from apatite fission-track analysis
}

\begin{abstract}
In the Montes de Toledo area, located in the axial part of the Central Hercynian zone, a long-term thermo-tectonic evolution can be deduced from apatite fission-track (AFT) data in conjunction with tight geological constraints derived from the knowledge of regional geology and other independent chronometers. The area is composed of two different blocks separated by the Toledo Shear Zone (TSZ). The northern block is a granulite facies anatectic terrane. The southern block is composed of greenschist facies Paleozoic sediments intruded by a late Hercynian granitic pluton. A total of 13 samples have been recovered for AFT analysis. AFT ages in both blocks cluster around $189221 \mathrm{Ma}$, with mean confined track lengths between $11.4 \mu \mathrm{m}$ and $12.4 \mu \mathrm{m}$. Modeling of the AFT data indicates that the thermal history is broadly similar in both blocks, which constrains the main movement of the TSZ, as essentially before the Upper Permian. AFT ages in the TSZ cluster around $124164 \mathrm{Ma}$, and the track lengths vary between $11.4 \mu \mathrm{m}$ and $12.4 \mu \mathrm{m}$. These data reveal that the fault must have been affected by a later thermal overprint as AFT ages are significantly younger than those of the footwall and hangingwall blocks. This differential thermal resetting is likely related to the advection of localized hydrothermal fluids that are responsible for the widespread $\mathrm{Pb} \mathrm{Zn}$ mineralization along the TSZ. These
\end{abstract}

L. Barbero $(\square)$

Departmento de Geologia, Facultad de Ciencias del Mar y Ambientales, Universidad de Cádiz, 11510 Puerto Real, Spain

E-mail: luis.barbero@uca.es

U. A. Glasmacher

Max-Planck-Institut für Kernphysik,

Postfach 103980, 69029 Heidelberg, Germany

C. Villaseca - C. Martín-Romera

Departmento de Petrología y Geoquímica,

Universidad Complutense, 28040 Madrid, Spain

J. A. López García

Departmento de Cristalografia y Mineralogía,

Universidad Complutense, 28040 Madrid, Spain results give an example of resetting AFT data by hydrothermal events. The long-term evolution suggests a lack of important Alpine tectonism in the Montes de Toledo block, in clear contrast to other nearby Hercynian areas such as the Sierra de Guadarrama, where the important effect of Alpine tectonism has almost totally erased the previous thermal signal in the AFT system.

Keywords Spanish Central Hercynian Zone - Apatite fission-track dating - Resetting related to fluids . Mesozoic and Cenozoic thermal history

\section{Introduction}

The Montes de Toledo and the Sierra de Guadarrama belong to an intraplate range (Central Iberian Zone) that originated from the stress migration toward the inner part of the Iberian microplate during two different Alpine collisional events (Fig. 1). The convergence between the Eurasia and Iberia plates during the Paleogene and Early Miocene led to the formation of the Pyrenees Cantabrian mountain range; and the convergence between the African and Iberian microplate from the Miocene to the present created the Betic Cordillera (Zoback 1992; Anderweg et al. 1999). Both collisional events affected the basement of the central part of the Hercynian Iberian Belt.

The Sierra de Guadarrama is the main relief in Central Spain reaching maximum altitudes of about $2,600 \mathrm{~m}$. The range trends parallel to the Betic Cordilleras, which suggests a possible tectonic control of the latter in the formation of the Sierra de Guadarrama (De Brujne 2001; de Bruijne and Andriessen 2000; De Bruijne and Andriessen 2002). The AFT-dating technique was used to quantify the far-field effects of the Alpine orogeny on the exhumation of the Sierra de Guadarrama (de Brujne and Andriessen 2002). In contrast, the northern part of the Montes de Toledo area, located $70 \mathrm{~km}$ to the south of the Guardarrama range, is 


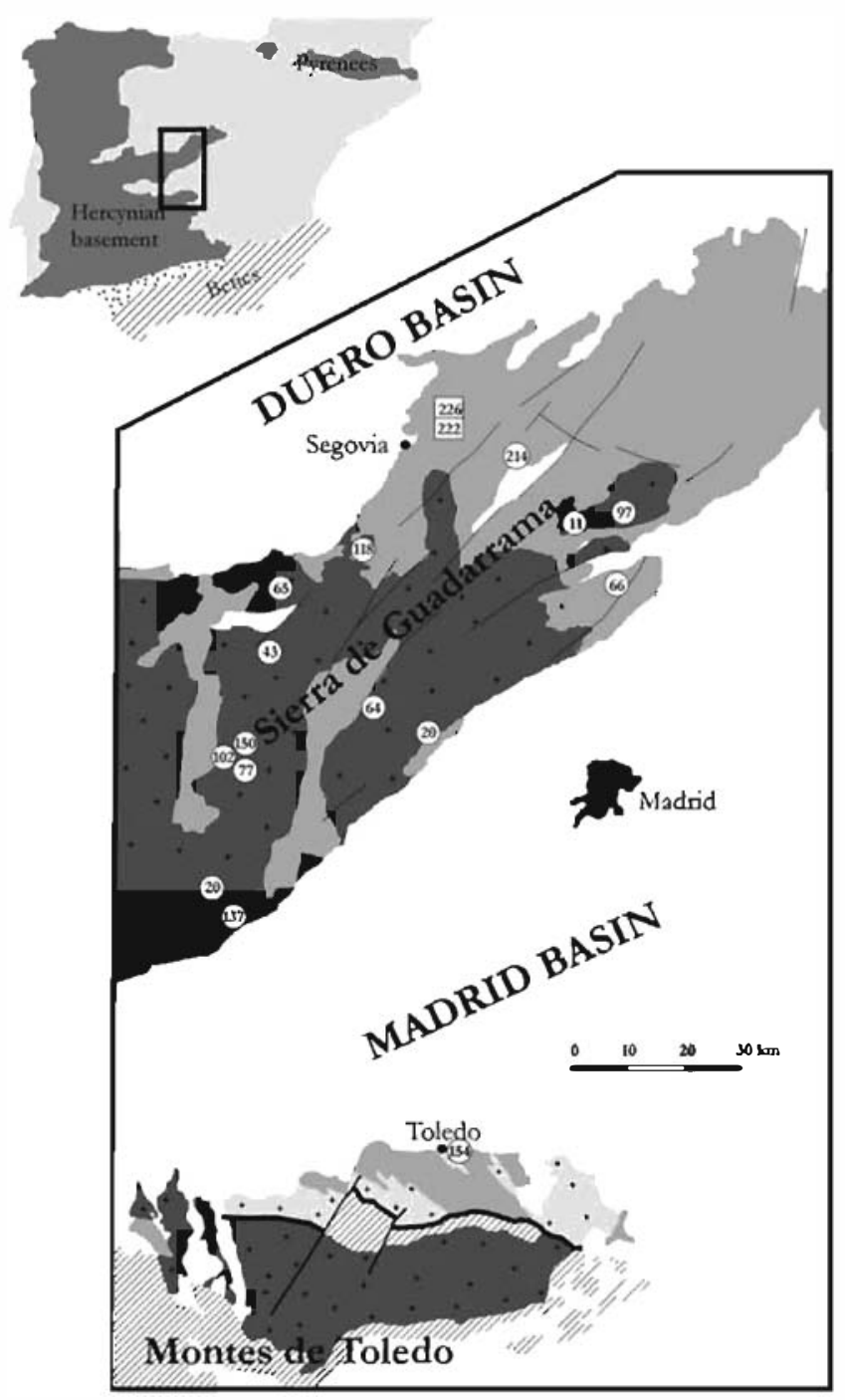

Terrary basins

Hercynian granitcs:

a) Post-orogenic

b) Sya-orogenic
High grade metamorphic rocks

Low grade metamorphic rocks

\section{Toledo Shear Zone}

Fig. 1 Location of the study area within the central part of the Spanish Central Hercynian Belt. Numbers in circles are AFT ages from De Brujne and Andriessen (2002). Numbers in squares are AFT ages from this work, sampled in the deepest part of the Sierra de Guadarrama

essentially a flat region with a mean elevation of about $650 \mathrm{~m}$. Dispersed inselbergs are constituted by Cambro

Ordovician sedimentary rocks. The low altitude of the northern Montes de Toledo area in comparison to the Sierra de Guadarrama region leads de Vicente et al. (1996) to conclude that exhumation of the Montes de Toledo occurred prior to the exhumation of the Sierra de Guadarrama. Furthermore, they assumed that the intensity of the alpine deformation was lower in the Montes de Toledo. Toward the south, the relief in the Montes de Toledo is more pronounced but never reaches the altitude of the Sierra de Guadarrama. The Montes

de Toledo area is aligned along an $\mathrm{E} \mathrm{W}$ direction that follows the trending of the Pyrenees Cantabrian range. Important $\mathrm{E} \mathrm{W}$ faults are present, including a thick mylonitic band, the Toledo Shear Zone (TSZ) of possible late Hercynian age.

The differential movements between the Iberian plate and the Eurasian and African plates during the progressive opening of the North Atlantic Ocean are the driving forces of the far-field effects that influenced the Iberian microplate during the Mesozoic and Cenocoic (Anderweg et al. 1999; Anderweg 2002). Rifting in the Gulf of Biscay ceased at about $85 \mathrm{Ma}$, causing the convergence of Eurasia and Iberia inducing a NNE N compressional stress field, which led to the inversion of the Mesozoic basins, now forming the Pyrenean and Iberian ranges. Differential motion between Iberia and Africa started at around $54 \mathrm{Ma}$. The final collision of Iberia with Eurasia occurred at around $30 \mathrm{Ma}$ and coincides with a major change in the active plate boundary in the Azores Gibraltar zone. The extension of Iberia induced by the eastward movement of Africa ended with the creation of the Valencia Trough at 23 $30 \mathrm{Ma}$. When the direction of the convergence changed from NNW to NW during the Miocene, the Betic Cordillera and the Central Iberian Zone were finally structured.

In the northern part of the Montes de Toledo, an apatite fission-track (AFT) study was undertaken to investigate (1) the thermal evolution and exhumation history of the area, (2) the role of the position of the Montes de Toledo area with respect to the main Alpine orogens at the margin of the Iberian plate, and (3) the importance of the pre-existing crustal weakness in the alpine evolution.

\section{Geological Setting}

The study area is located south of Madrid and is part of the Central Iberian Zone (Fig. 1). The Central Iberian Zone has been demarcated by Alpine brittle fracture zones leading to basins filled with Cenozoic sediments and raised crystalline blocks. The northern limit of the Montes de Toledo area is an E W Alpine fracture zone, which separates Cenozoic sediments of the Madrid basin from the high-grade rocks of the Hercynian Anatectic Complex of Toledo (ACT) (Fig. 2). The southern limb of the so-called Sonseca anticlinorium constitutes the southern limit of the study area. An E W elongated granite batholith (Mora batholith) intrudes the Sonseca anticlinorium at about $320 \mathrm{Ma}$ ( $\mathrm{Rb}$ Sr method), (Andonaegui 1990). Based on barometry, the depth of intrusion is estimated to be approximately 2 kbar (Andonaegui 1990). The northern limb of the Sonseca anticlinorium is partially disrupted by a low angle, gently S-dipping normal fracture zone, the so-called Toledo ductile brittle shear zone (Toledo mylonite), which exhibits a listric geometry at depth (Hernández Enrile 1991; Santa Teresa et al. 1983). Along the shear zone, 


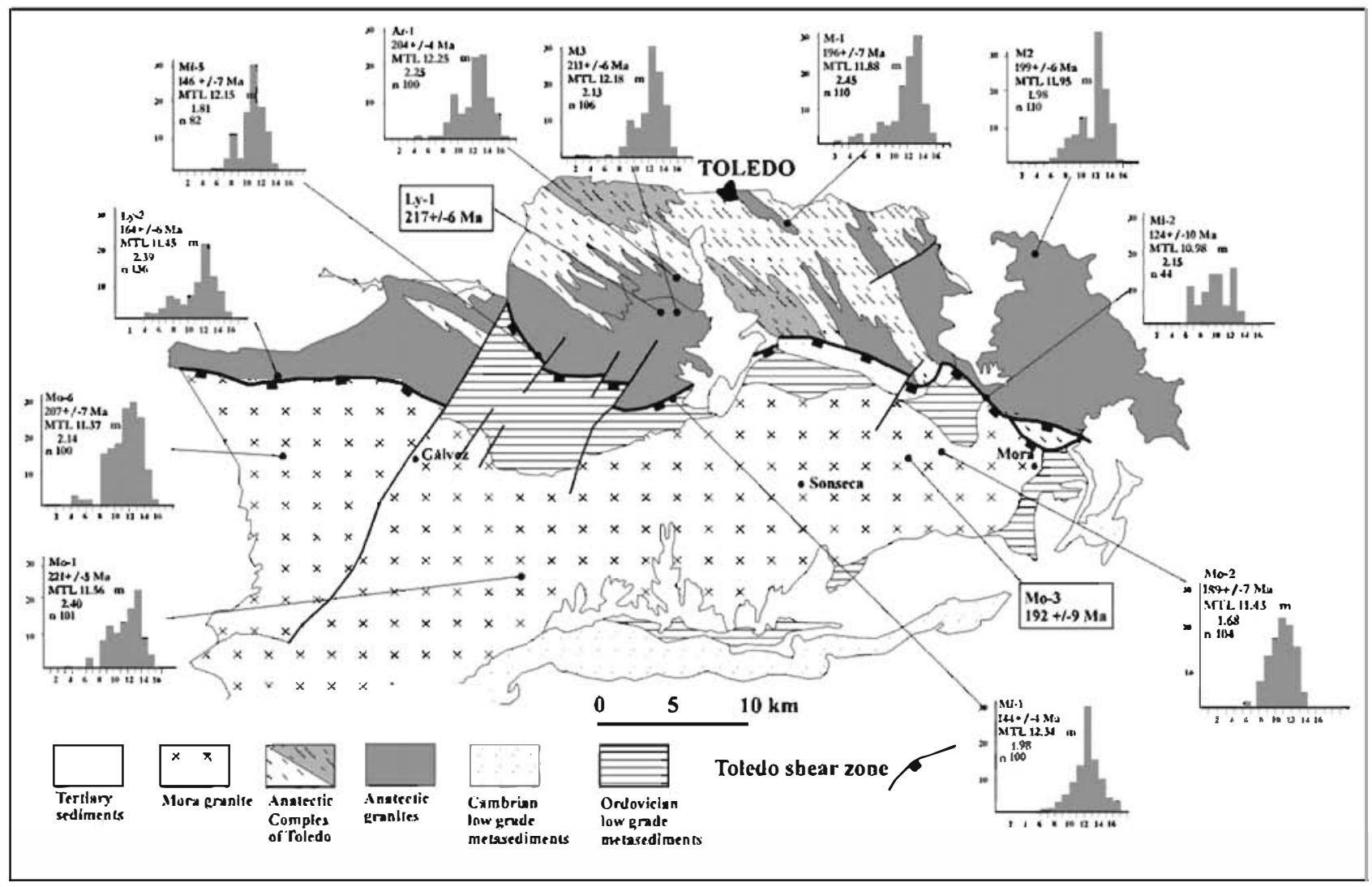

Fig. 2 Geological map of the Toledo Mountains with AFT ages and track-length measurements

the Mora batholith is in contact with the high-grade rocks of the ACT. The ACT equilibrated at intermediate- $\mathrm{P}$, granulite facies conditions $\left(800850^{\circ} \mathrm{C}, 46 \mathrm{kbar}\right)$ (Barbero 1995). The age of the granulite metamorphism has been a topic of considerable debate. $\mathrm{U} \mathrm{Pb}$ ages of monazite from granites within the ACT indicate that the most likely age of metamorphism is before $305312 \mathrm{Ma}$ (Barbero and Rogers 1999). K Ar cooling ages of biotites (Aparicio et al. 1990; Barbero 2004) indicate that cooling through the $300^{\circ} \mathrm{C}$ isotherm occurred at approximately $265270 \mathrm{Ma}$.

The TSZ is a significant extensional structure with a large amount of displacement as revealed by about $3 \mathrm{kbar}$ differences in formation pressure between the ACT and the Mora batholith (Barbero 1995). The kinematics of the TSZ has been well established by Hernández Enrile (1991). The research by this author evidences that the TSZ has evolved from ductile to brittle conditions, the tectonic transport being always with a normal sense. Hernández Enrile (1991) gives a post-orogenic Permian age for the TSZ; meanwhile, Barbero (1995), on the basis of the metamorphic evolution of the ACT suggested that the fault could be essentially syn-orogenic, probably related to the extension during the gravitational collapse of the previously thickened crust. Deformational features in the northern part of the Mora batholith suggest that its emplacement could be related to the latest stages of movement in the TSZ. The TSZ is cut by a NNE SSW transcurrent sinistral fault system, which clearly postdates the TSZ movement.

In certain parts of the northern limit of the Montes de Toledo, some remains of post-Palaeozoic detrital sediments and limestones crop out. They overlay the highgrade metamorphic rocks and an Upper Cretaceous stratigraphic age has been assigned to this formation by Sánchez Carretero et al. (2004). In other parts, abundant Cenozoic detrital sediments overlay the Palaeozoic rocks at both sides of the TSZ. The age of this sedimentary cover is Middle Miocene and from the composition of the sediments, the source areas must be the Ordovician quartzites of the low-grade Palaeozoic rocks of the Sonseca Anticlinorium (Sánchez Carretero et al. 2004). The presence of these sediments of Upper Cretaceous and Middle Miocene ages indicates that the area must have resided near the surface during at least these two periods.

\section{Apatite fission-track analysis}

Spontaneous fission of ${ }^{238} \mathrm{U}$ contained in trace amounts in minerals creates latent tracks, a linear accumulation of crystal defects, which, once properly etched, can be resolved by means of an optical microscope. In AFT are shortened during heating at a rate dependent on the temperature, duration of heating, crystallographic orientation (Green and Durrani 
1977; Galbraith and Laslett 1988; Galbraith 2002; Donelick et al. 1999; Ketcham 2003), and chemical composition mainly in terms of $\mathrm{F}$ and $\mathrm{Cl}$ contents (Green et al. 1985, 1986; Donelick 1993; Burtner et al. 1994; Barbarand et al. 2003). The result of this annealing process is that the initial length of $1516 \mu \mathrm{m}$ is shortened if the heating temperature is in the range of $60120^{\circ} \mathrm{C}$ during geological time scales. For this reason, the cooling heating path experienced by a particular sample will result in a particular fissiontrack length. Fast cooling through the partial annealing zone (PAZ) will result in narrow track-length distributions with track lengths $>14 \mu \mathrm{m}$. More complex thermal histories involving several cooling heating events or slow cooling through the PAZ will result in broader track-length distributions. For a comprehensive overview of fission-track theory, the reader is referred to Gleadow et al. (1986) and Wagner and van den Haute (1992) and references therein. Using experimental annealing results of apatites with different chemical compositions and inverse modeling via Monte Carlo and genetic algorithms simulations (Laslett et al. 1987; Gallagher 1995; Ketcham et al. 2000), a set of thermal histories that fits both tracklength distribution and fission-track age can be obtained. The success in finding a coherent thermal history by modeling can be highly dependent on the appropriate use of the known geological constraints imposed on the models. Fission-track thermochronology is applied to solve different geological problems, the most popular ones being those related to denudation history of basement rocks in different tectonic settings. In the presence of major faults, resolving the thermal history at both sides of the fault, AFT data may result in constraining the age of the fault.

The presence of a varied series of peraluminous highgrade metamorphic rocks and a late Hercynian pluton enable the recovery of an abundance of apatite crystals form the 13 samples. Apatites have been recovered from five samples taken from different types of granites (Argés pre-metamorphic peak granite, the Layos granite, and Moncloa granite) of the ACT. Apatites are large (up to $500 \mu \mathrm{m})$ and euhedral. Four samples have been taken from the Toledo mylonite (TSZ). As the TSZ affects different types of materials of the ACT, some of the samples can be classified as mesocratic mylonites (those having the Layos granite as protolith) or leucocratic mylonites (those having Cervatos type anatectic leucogranites as protoliths). In Fig. 3, the position of these samples in relation to the mineralizations in the TSZ is marked. Some of the samples are clearly close to known mineralization sites, but one sample (Mi-5) is not apparently close to any evident mineralization. Four samples have been collected in the Late-Hercynian Mora Granite. The apatites are euhedral and counting has been performed in those having homogenous fossil fission-track distributions.

The $\zeta$ approach (Hurford and Green 1983) has been used for fission-track analyses of individual apatite crystals. Apatites have been mounted in U-free glass with clear epoxy resin and polished using $1 \mu \mathrm{m}$ and $3 \mu \mathrm{m}$ diamond slurries. Etching for revealing fossil tracks has been performed using $5 \mathrm{M} \mathrm{HNO}_{3}$, at $20 \pm 0.5^{\circ} \mathrm{C}$, for $20 \pm 1 \mathrm{~s}$. After etching, each sample was rinsed with water to ensure the termination of the etching process. The external detector method has been used by applying U-free clear ruby muscovite as external detectors. Two $\mathrm{CN}-5$ dosimeters were place at the top and bottom of the irradiation capsule to ensure that neutron doses and gradients could be calculated. Irradiation with thermal neutrons at a fluence of $9 \times 10^{15} \mathrm{n} /$ $\mathrm{cm}^{2}$ was done at HIFAR (Australia). After irradiation, muscovites were etched by concentrated hydrofluoric acid at room temperature for $40 \mathrm{~min}$. Counting was performed using a Zeiss Axioskop 2 microscope (100x dry objective and $1,250 \times$ total magnification) equipped with a Kinetek automated stage. For track-length measurements, a drawing tube linked to a computer-controlled Creation Station Pro digital tablet with a tiny red LED in the cursor was used. Calibration of the tablet was made by repeated $(n=50)$ measurements using a graticules $100 \mu \mathrm{m}$ with $2 \mu \mathrm{m}$ divisions.

\section{Apatite fission-track results}

In Table 1 and Fig. 2, apatite fission-track ages and track-length distribution of analyzed samples are displayed. With the exception of samples Ly-2 and Mi-5, all individual apatite grain ages in one sample belong to one homogeneous population as revealed by the reported probability $\left(P\left(\chi^{2}\right)>5 \%\right)$ of the chi-squared test (Table 1). AFT ages vary from $221 \pm 5$ (Mo-1) to $189 \pm 7$ Ma (Mo-2), with the exception of the TSZ mylonite samples. No age differences are evident between the northern (ACT) and southern blocks (Mora batholith). All AFT ages are younger than the intrusion age of the granites $(320 \mathrm{Ma})$ or the age of the granulite facies metamorphism (305 $312 \mathrm{Ma}$ ) of the ACT (Barbero and Rogers 1999).

All samples of the TSZ mylonite show AFT ages in the range of $124 \pm 10 \mathrm{Ma}$ to $164 \pm 6 \mathrm{Ma}$. These ages are much younger than those at both from the ACT and Mora batholith. As observed in the rest of the samples, it seems that AFT ages in the TSZ exhibit a weak trend of younger ages toward the east.

Track-lengths distributions in non-mylonitic samples are characterized by average means between $11.4 \mu \mathrm{m}$ and $12.2 \mu \mathrm{m}$ and standard deviations from $2.0 \mu \mathrm{m}$ to $2.4 \mu \mathrm{m}$. The length histograms are negatively skewed and in certain cases as in sample Ar-1 clearly bimodal, which points to a complex thermal history. Apatites from the mylonites show shorter average track lengths from $9.9 \mu \mathrm{m}$ to $12.3 \mu \mathrm{m}$ with standard deviations from 2.0 to 2.6. The length histograms are also negatively skewed but not clearly bimodal. Again, samples from the east show shorter mean track lengths compared to those located further to the west. 


\section{Results from AFT data modeling}

Modeling via Monte Carlo simulations (Gallagher 1995; Ketcham et al. 2000) can be a powerful tool to unravel the thermal history of a particular area, but as several fitting models are statistically possible, a cautious approach is necessary. In this respect, geological restrictions, when available, can help in choosing a particular solution. Two approaches are mostly used to perform thermal modeling of AFT data. Gallagher (1995) used a Monte Carlo simulation coupled with a genetic algorithm to generate several thousands of paths within specific $\mathrm{t}-\mathrm{T}$ boxes based on the information from the FT data and geological constraints. Applying a specific annealing model to those trajectories generates an output, which is a range of thermal histories that fit the fission-track age and confined track-length distribution within certain goodness of fit. The approach of Ketcham et al. (2000) is similar to that of Gallagher but incorporates etching characteristics of the apatites, as initial mean track length is dependent on this factor. In the present study, inverse thermal models have being obtained by using the AFTSolve software of Ketcham et al. (2000).

The results of modeling are presented in Figs. 3 and 4 for all samples of the Montes de Toledo area. The annealing model for Durango apatite of Laslett et al. (1987) was used. Several geological constraints have
Fig. 3 Selected thermal models for three samples of the Toledo Mountains. M-1 from the northern block; Mi-1 from the TSZ; and Mo-2 from the southern block. Models have been calculated using the AFTSolve software from Ketcham et al. (2000). Light shaded area represents acceptable fit; dark area represents good fit. G.O.F. is goodness of fit
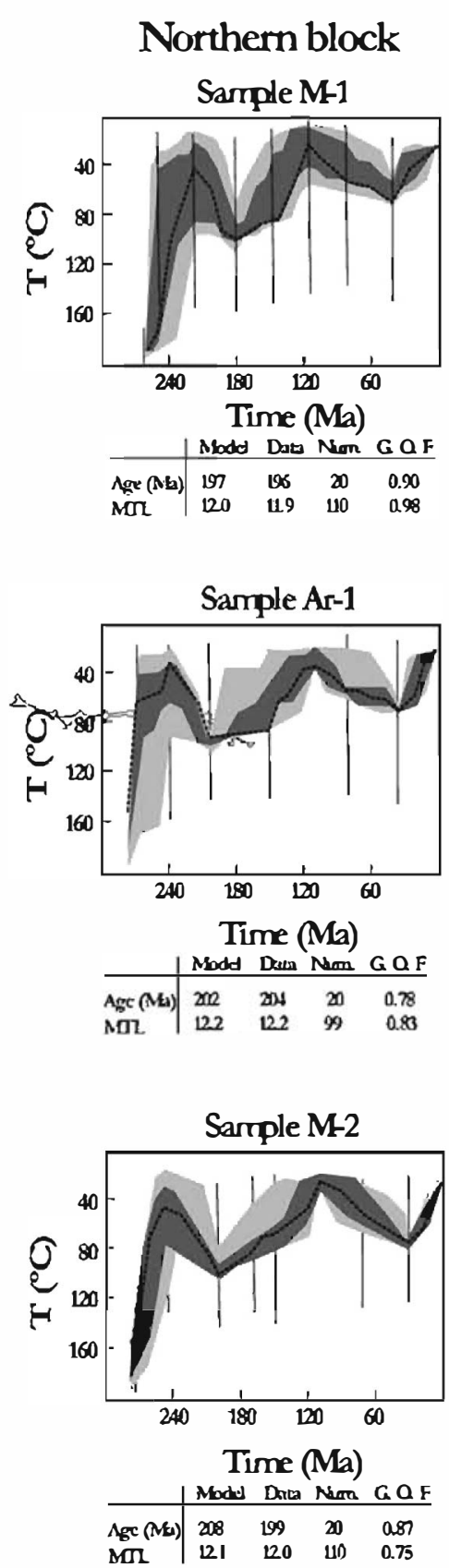

Southern block

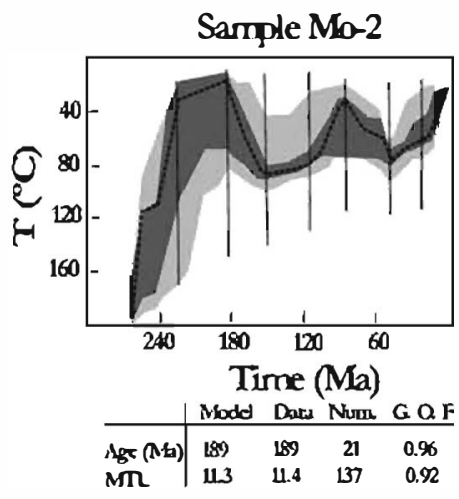

Sample Mo-1
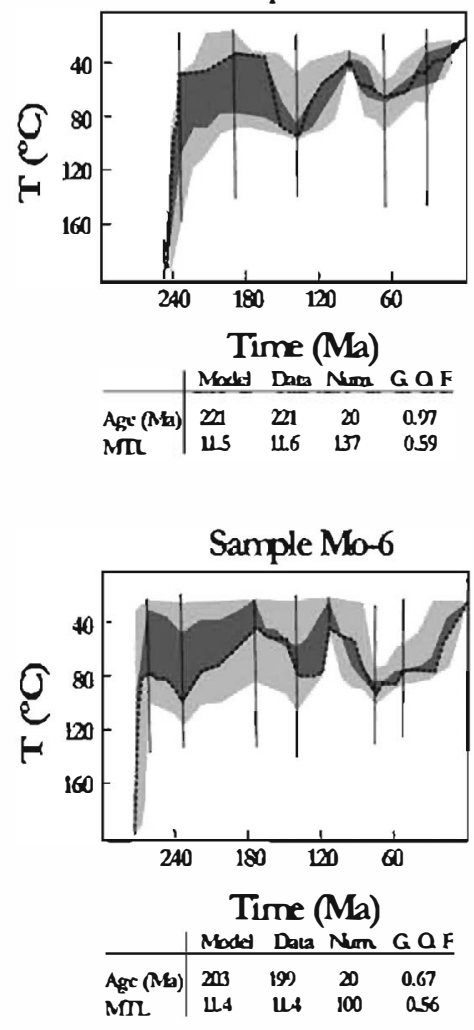


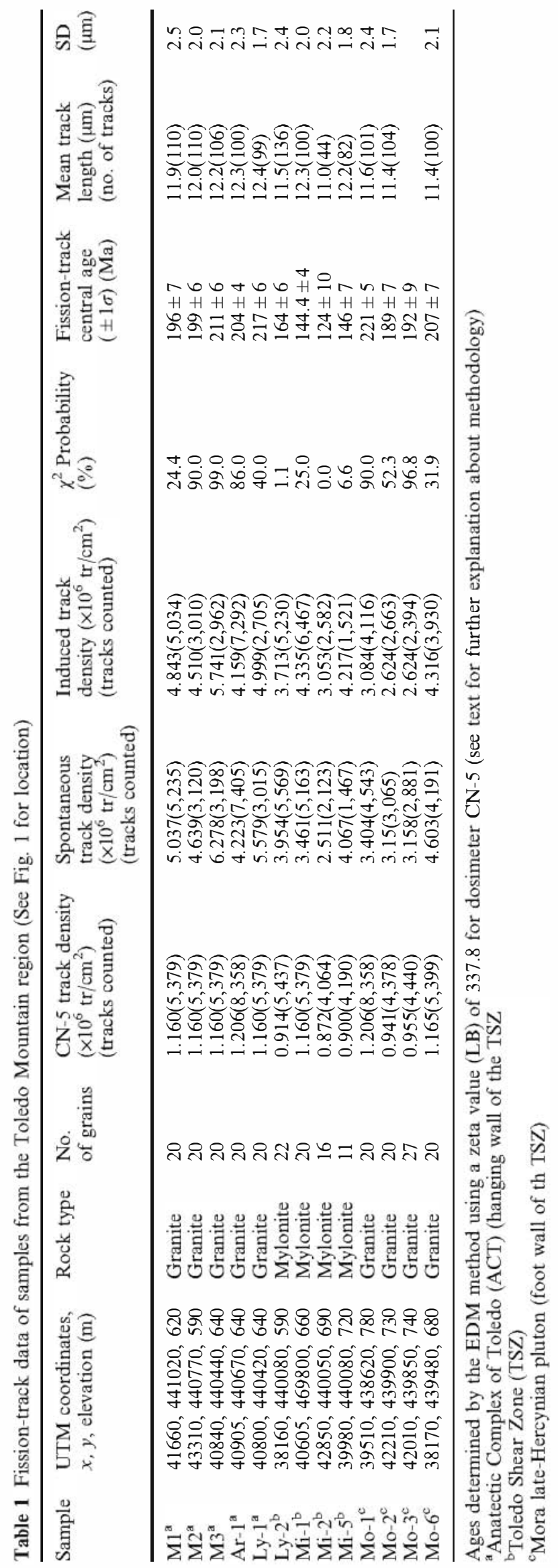

been included in the models. The first one is the $\mathrm{K} \mathrm{Ar}$ cooling ages $\left(300^{\circ} \mathrm{C}\right.$ at about $\left.265 \mathrm{Ma}\right)$ obtained for biotites from samples of the ACT (Aparicio et al. 1990; Barbero and Rogers 1999) and the intrusion age of the Mora granite batholith (Andonaegui 1990). The second constraint is related to the Albian detrital sediments that directly overlie the metamorphic rocks of the ACT (Sánchez Carretero et al. 2004), which is a clear indication that the crystalline basement was at the surface by that time. Mean surface temperature during Albian times has been estimated to be around $2729 \mathrm{degrC}$ following the work of Wygrala (1989), considering that the Iberian plate was probably located at paleolatitude of $25^{\circ} \mathrm{N}$ to $30^{\circ} \mathrm{N}$ (Dercourt et al. 2000), thus presenting a subtropical, semiarid to humid climate (Giménez et al. 1993). The last constraint imposed on the models is the presence of conglomerates of Miocene age directly on the top of the ACT, the TSZ, the Cambro Ordovician low-grade metasediments and the Mora granite batholith (Sánchez Carretero et al. 2004).

Modeling of the samples from the Mora granite batholith (Mo-2, Mo-1 and Mo-6) give indication of three different cooling episodes separated by two heating events (Fig. 4). These heating cooling episodes seem to be very consistent from east to west along the $60 \mathrm{~km}$ of maximum extension of the Mora batholith. The first recognized cooling episode occurred during the Upper Permian to Lower Triassic at rates of 4 $10^{\circ} \mathrm{C} / \mathrm{Ma}$, leaving the basement close to surface levels by late Permian to early Triassic times. Following this Permian Triassic cooling episode, a well-defined heating episode is seen in the Mora batholith. This heating finishes at about late Oxfordian times $(150 \mathrm{Ma})$ at temperatures of approximately $8090^{\circ} \mathrm{C}$. The heating rate was approximately between 1.7 and $2.2^{\circ} \mathrm{C} / \mathrm{Ma}$. A second cooling event follows, reaching minimum temperatures close to the surface by Barremian Cenomanian times. The second heating episode at rates of around $1{ }^{\circ} \mathrm{C} / \mathrm{Ma}$ is also well recognized in the whole batholith and reaches maximum temperatures between $60^{\circ} \mathrm{C}$ and $80^{\circ} \mathrm{C}$ at approximately the Cretaceous Tertiary boundary (75 $50 \mathrm{Ma})$. Subsequent cooling toward present day temperatures occurred. The resolution of the models was not enough to test if by Early Miocene times, the materials were at the surface as indicated by the presence of Miocene deposits on the top of the granites.

In the footwall block (ACT) of the TSZ, the modeling performed on materials of the ACT show similar results to that for the hanging wall block (Mora batholith), which strongly suggest a similar thermal history for both blocks, since Permian time. This evidences a pre-Permian age for the TSZ.

For modeling the AFT data of the TSZ, the temperature restrictions that can be obtained for the study of the mineralization found in the fault have to be considered. The mineralization, which is under investigation, (López Garcia et al. 2003) crosscut the mylonitic structure and therefore, postdates the formation of the 


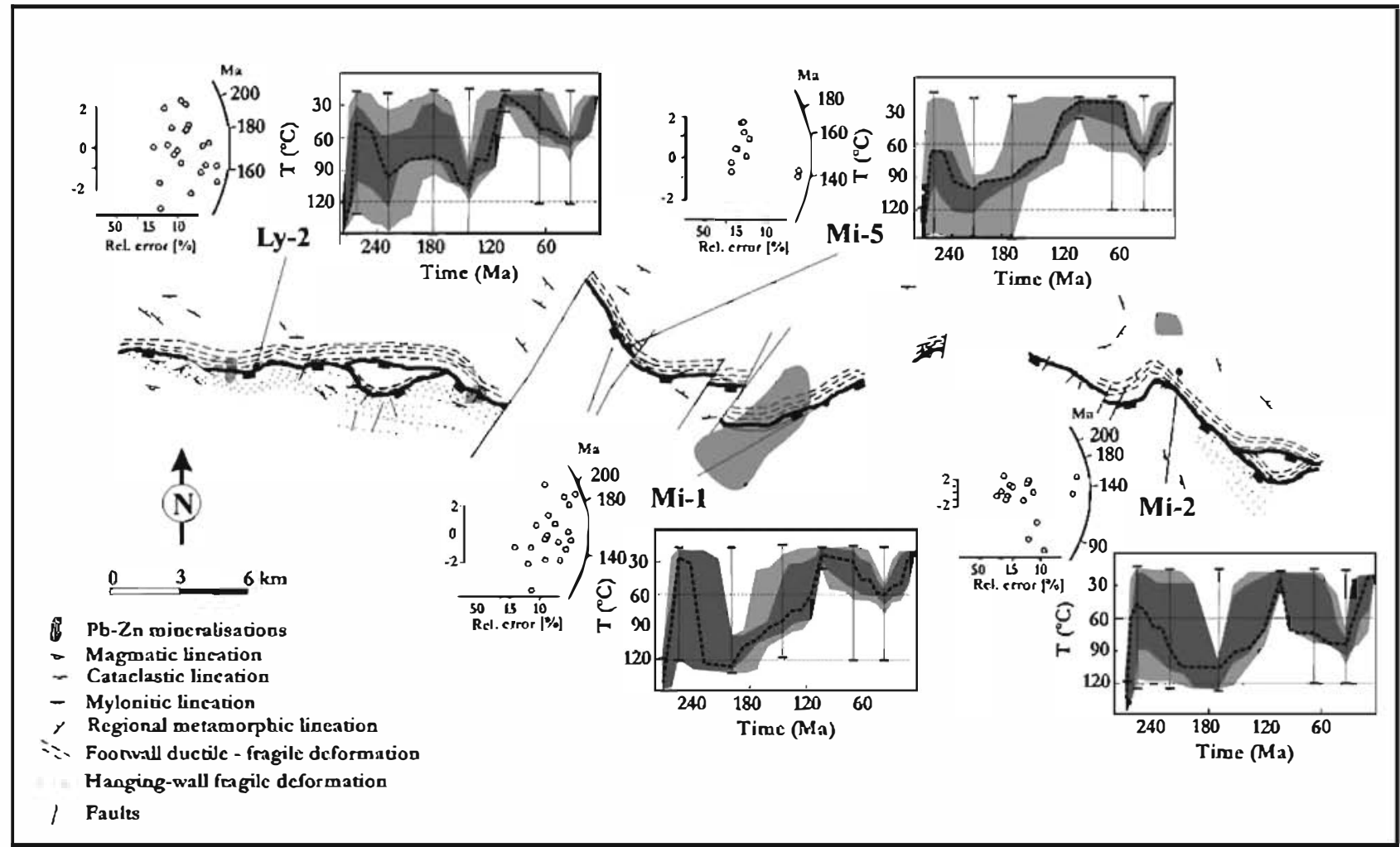

Fig. 4 Radial plots and results of AFT thermal modeling in mylonite samples from the TSZ. Light and dark shaded areas as in Fig. 3

TSZ. In general, two mineralization stages can be defined in the deposit. The first stage consists of a general silicification with disperse pyrite and arsenopyrite crystals. The second one consists of silification and carbonatization (siderite) with barite, galena, chalcopyrite, Fe-poor sphalerite and gersdorfite-type Ni Co sulfoarsenides. Temperatures of the deposition of the minerals that are calculated on the basis of oxygen isotopes thermometry give temperatures in the range of 140 $210^{\circ} \mathrm{C}$ (López García et al. 2003). The thermal history after the mineralizing event is similar to that observed for the samples to the north or south of the TSZ.

\section{Discussion}

Similar AFT ages and similar T-t paths at both sides of the TSZ indicate that both blocks (ACT, Mora granite batholith) were exhumed during the same event. Minor differences in AFT ages appear from one sample to another, which could be related to slightly differential exhumation due to the NNE SSW transcurrent fault system. The slight polarity observed toward younger AFT ages from west to east could be the result of tilting of the whole block during exhumation.

Apatite fission-track ages in the Toledo mylonite are noticeably younger than those in the hanging (ACT) and footwall (Mora granite batholith) blocks. This might be the result of a thermal event that affected only the rocks within the mylonite, and not those in the foot and hanging wall. A thermal event affecting the TSZ can only be related to the formation of the $\mathrm{Pb} \mathrm{Zn} \mathrm{Cu}$ mineralization that is found in certain places of the TSZ. Temperatures calculated for the deposition of the mineralization are high enough to produce total annealing of latent fission tracks in apatite. Therefore, it seems to be very likely that in the Mesozoic, convective heat transport by hot fluid migration through the TSZ, totally reset the fission-track system in apatites. Models were created by allowing high $\mathrm{T}$ prior to approximately $150 \mathrm{Ma}$, which is the ATF ages obtained for samples from the Toledo mylonite. Modeling results indicate that high temperatures at around $190 \mathrm{Ma}$ satisfactorily explain the AFT data observed. The age of $190 \mathrm{Ma}$ is interpreted to be a minimum age for the formation of the mineralization.

Cooling and heating episodes obtained by thermal modeling of fission-track data have to be resolved either in terms of variations in the paleogeothermal gradients with time or in terms of exhumation processes. The decision as to which process might strongly influence the modeled T-t path depends on the knowledge of the paleothermal gradients and the variation of these gradients through time. These last two parameters are difficult to evaluate in a scenario like the one considered in the present study. Nevertheless, the position of the Montes de Toledo in an area that is far from plate boundaries and the absence of important magmatism since Permian times apart from the scarce N S alkaline dykes of Triassic age (Villaseca and Nuez 1986) are arguments that 
might point toward a stable paleogeothermal conductive gradient since the Permian. Also, the advection of geotherms related to rapid denudation (Mancktelow and Grasemann 1997) seems to be very unlikely on the basis of the slow cooling rates recognized in the area.

Based on AFT models, one can emphasize an initial Upper Permian to Lower Triassic cooling period for the hanging and footwall of the TSZ occurring at rates of 4 $10^{\circ} \mathrm{C} / \mathrm{Ma}$. No sedimentary deposits of these ages have been found in direct relation to the basement rocks either in the study area or in the Sierra de Guadarrama or Gredos region. This could indicate that during the Late Permian Lower Triassic interval, the whole area underwent erosion.

Furthermore, considering the closure temperatures of the high-temperature thermochronometers, the cooling path of the footwall (ACT) of the TSZ can be extended to the Upper Carboniferous. $\mathrm{U} \mathrm{Pb}$ ages obtained from monazites of the granites in the ACT are in the range of $305312 \mathrm{Ma}$ (Barbero and Rogers 1999). K Ar ages of biotites from the same samples are between $265 \mathrm{Ma}$ and 270 Ma (Barbero 2004). Considering a closing temperature of about $750^{\circ} \mathrm{C}$ for the $\mathrm{U} \mathrm{Pb}$ system (Parrish 1990) in monazite and about $300^{\circ} \mathrm{C}$ for $\mathrm{K} \mathrm{Ar}$ in biotite, the cooling rates obtained are in the range of $1013^{\circ} \mathrm{C} / \mathrm{Ma}$ from the Upper Carboniferous to Upper Permian. Considering the Upper Carboniferous intrusion age ( $320 \mathrm{Ma}$ ) of the Mora granite batholith and the AFT cooling path in Upper Permian to Lower Triassic time, the cooling rates are less than in the hanging wall of the TSZ. It cannot be excluded that movement along the TSZ leads to exhumation of the ACT in Upper Carboniferous to Upper Permian time. A major conclusion that can be drawn from these observations is that the TSZ is an intra-Hercynian structure that has never been significantly reactivated since Upper Permian times. AFT data together with other geochronological evidences presented here indicate that post-Upper Permian exhumation related cooling would occur via erosion. Exhumation due to normal faulting would commonly result in abrupt breaks in the cooling pattern at both sides of a fault, with the youngest ages in the footwall block (Wagner and van den Haute 1992; Ring et al. 1999), which is not the case in the Montes de Toledo area.

Paleogeothermal gradients at the time of the formation of the ACT can be calculated using the thermobarometric estimations based on mineral equilibria (Barbero 1992, 1995). Metamorphic peak conditions in the ACT are $46 \mathrm{kbar}$ and $800850^{\circ} \mathrm{C}$. These conditions imply a geothermal gradient of about $50^{\circ} \mathrm{C} / \mathrm{km}$. In comparison to the fission-track data, the first cooling episode recorded in the fission-track T-t models represents a transition toward lower geothermal gradients rather than representing exhumation via erosion, or a combination of both processes as discussed by Ziegler (1990). Thermal subsidence probably accompanied this cooling episode, as it was the case of the Permian basins located to the north of the inactive Hercynian belt
(Ziegler 1990). Thus, the cooling episode during the Upper Carboniferous Early Triassic might result from a combination of (a) the relaxation of the thermal anomalies introduced during the last stages of the Hercynian orogeny, (b) the progressive exhumation via erosion of the relief of the Hercynian Fold Belt, as evidenced by the presence of flysch deposits of Upper Carboniferous ages located toward the south and north of the Central Iberian Zone, (c) the thermal subsidence related to the rifting in the Bay of Biscay that is reactivated during the Late Permian as indicated by the accumulation of clastic continental deposits (Virgili et al. 1983; Sopeña et al. 1983).

This first cooling episode was followed by a heating period, which ended in Late Jurassic times and was probably the result of the end of the relaxation of the Hercynian thermal anomalies and the subsequent dominance of the thermal subsidence processes related to rifting. No sedimentary deposits of these ages have been found directly on top of the Mora batholith nor on top of the ACT, but the results from modeling point to a position of the batholith close to the surface by Lower Cretaceous times. The origin of this heating might therefore be related to far-field effects of the rifting process, which opened the Tethys Ocean. Thermal histories obtained by modeling apatite fission-track data (Barbero et al. 2001, 2002) from samples of Albian (108 $96 \mathrm{Ma}$ ) sediments from the external Betics (the southern Iberian paleomargin), are very similar to those recorded in the Montes de Toledo area (Fig. 4). The Albian sediments never reached temperatures in excess of $7080^{\circ} \mathrm{C}$. Therefore, the inherited thermal signal of the fissiontrack system in apatite is well conserved. The similarities of the time-temperature paths imply a direct link between the thermal histories registered at the continental margin and those at the plate's interior. The south Iberian continental margin evolved during Triassic Oxfordian as a typical intracontinental-rifted margin, with an initial stage during the Triassic-Lower Pliensbachian characterized by notable thickness changes in the stratigraphic units and by the occurrence of synsedimentary normal listric faults affecting Jurassic rocks (Vera 2001). The appearance of mantle-derived tholeiitic basalts intercalated in Upper Triassic sediments in certain parts of the Iberian continental margin also strongly favors this initial intracontinental margin stage related to the Tethys opening (Vera 2001). The main intracontinental margin stage that follows is characterized by a major change in the depositional environment, from shallow to more basinal environments (Vera 2001). The absence of sediments of Triassic Jurassic age in the Central Iberian zone precludes any interpretation of its evolution to be made on this basis, leaving the thermal signal registered in the fission tracks as one of the few evidences of the rifting evolution during this time span. Nevertheless, the presence of anorogenic alkaline dykes of Triassic age in the Central Iberian zone cut by the Messejana Plasencia tholeiitic dyke, which is dated in the range of $203184 \mathrm{Ma}$ (Dunn et al. 1998; Schermer- 
horn et al. 1978), is another indication of an active rifting process related to the initial opening of the Atlantic during Triassic Jurassic times (Villaseca et al. 1992; Villaseca et al. 1999), and could also account for the increase in the geothermal gradient during rifting. In summary, it seems that the Central Iberian zone underwent heating in response to the rifting process related to the initial north Atlantic opening as well as to the propagation of the Tethys rifting in the southern margin.

The end of the Triassic Jurassic rifting stage is well marked by a cooling event starting during the Oxfordian $(150 \mathrm{Ma})$ and ending when rocks reached surface temperatures by Albian times (110 Ma). As stated by Ziegler (1990), grabens continued to subside and the horst became uplifted due to lithosphere stretching during late Jurassic to Early Cretaceous. This effect of thermal doming is particularly evident in Iberia by the presence of continental detrital deposits onto the eastern shelf facing the Tethys paleoocean, the Albian deposits in the external Betic margin that were mentioned, where shallow marine carbonates were accumulated during the late Jurassic (Ziegler 1990). Therefore, it is likely that the thermal doming due to stretching has the consequence of provoking a regional cooling effect of the uplifted areas, as is evidenced by the cooling period registered in the AFT models, both in the Central Iberian zone and in the external Betics. This latter can be considered as the rift flank, as evidenced by the presence of shallow marine deposits in greater quantities than a typical basinal area that would show heating related to subsidence.

Throughout the Cretaceous, a remarkably synchronous and widespread subsidence event is recognized in the Iberian microplate. This is particularly evident in the surrounding sedimentary basins on the basis of subsidence curves (Schwentke and Kuhnt 1992; Gräfe and Wiedmann 1993; Ziegler et al. 1995; Stapel et al. 1996, Martín-Chivelet 1997) and has also become evident by a heating period exhibited by fission-track-based thermal models in the external Betics (Barbero et al. 2001, 2002). This heating period is also shown by the thermal models based on AFT data in the Montes de Toledo area and confirms that the Cretaceous subsidence event took place on the whole Iberian plate scale. Following Reicherter and Pletsch (2000), this was largely due to the convergence between the African and Iberian plates with some effect of the opening of the North Atlantic Ocean and the closing of the Bay of Biscay. The onset of compression due to the collision of the Iberian and European plate that raised the Pyrenees occurred at around $60 \mathrm{Ma}$. Although, it is expected that this would have a reflection in the fission-track thermal models, no significant heating or cooling event is recognized in the Montes de Toledo area. This could indicate that by that time, the possible pre-existing weakness zones were either firmly welded (this could be the case of the TSZ, which became hardened after the mineralization event) or misoriented with respect to the stress field at that time, thus presenting a very rigid behavior.
Finally, the regional cooling event at about $20 \mathrm{Ma}$ suggested by thermal models not only in the Montes de Toledo area, but also all around the Iberian plate (Reicherter and Pletsch 2000; Barbero et al. 2001, 2002) marks the onset of the extensional collapse related to the collision between the African and European plates (Sosson et al. 1998). A thin sheet of Miocene conglomerates overlies part of the study area. These conglomerates indicate erosion of an uplifted part of the study area.

As already noticed by other authors (De Vicente et al. 1996), the lack of important topographic relief in the Montes de Toledo compared to the adjacent areas indicates that far-field effects of the Alpine orogeny were less intense and that the possible effects of these tectonism occurred first. The recognition that several cooling heating events occurred from late Paleozoic until the present in the Montes de Toledo, an area that since the Hercynian orogeny has always been located far from plate borders, has to be related to far-field effects of post-Hercynian tectonism. In this respect, the extent of the far-field effects is closely related to the geometric position of the pre-existing weakness zones with respect to the direction of the regional stress fields. As a first approximation, the Sierra de Guadarrama would be mainly controlled by the interaction between the Iberian and the African plates, as the position of the Sierra de Guadarrama is parallel to the currently active Betic Cordillera (De Bruijne and Andriessen 2000; De Bruijne and Andriessen 2002; Cloetingh et al. 2002), and in the same way, the Montes de Toledo area, which presents an E W trend, would be controlled by the interaction between the Iberian and Eurasian plates. This is not just consistent with the orientations of the stress fields with respect to the position of both mountain ranges but also with the timing of plate interactions, as the collision between Iberia and Eurasia occurred first, the Montes de Toledo area having more time to be dismantled. As Alpine tectonism had little effect in the Montes de Toledo area, variations in thermal history are recorded through a long-time span in the AFT ages.

\section{Conclusions}

Several points arise from the study of fission tracks in apatite and subsequent thermal modeling of the AFT data in the Montes de Toledo area.

1. The thermal evolution of the hanging and footwall block both sides of the TSZ as deduced from modeling reveal that the Montes de Toledo area was exhumed as a unique block in Mesozoic and Cenozoic times. Therefore, the development of the TSZ is older than the Upper Permian.

2. The initial Permo-Triassic cooling observed represents a combination of processes such as the transition from high geothermal gradients at the end of the Hercynian orogeny toward lower postorogenic gra- 
dients; the progressive exhumation by erosion of a Hercynian relief, and the thermal subsidence related to rifting in the Bay of Biscay.

3. The first heating period, which ended in Late Jurassic times, is related to far-field effects of the rifting process that opened the north Atlantic ocean. The end of the Triassic Jurassic rifting is well marked by a cooling event starting during the Oxfordian and ending by Albian times. This cooling is interpreted as the result of thermal doming due to stretching of the previously uplifted areas, and it seems to be a regional feature as it is also evidenced in rift flank areas such as the external Betics.

4. The Cretaceous heating event that follows represents a subsidence event recognized in the whole Iberian microplate and is related to the convergence of the African and Iberian plates with marginal effects of the north Atlantic ocean opening and the closing of the Bay of Biscay.

5. The final cooling event at around $20 \mathrm{Ma}$ marks the onset of the extensional collapse related to the collision of the African and European plates and thus represents another far-field effect of the events occurring at plate boundaries.

6. Finally, the role of advective heat transfer by localized hydrothermal fluids in resetting the fission-track system of apatite was shown in the Montes de Toledo area. Fission-track ages in the TSZ are much younger than those in the footwall- and hanging wall blocks, and in the absence of any differences in elevation, the presence of hydrothermal fluids could be invoked to explain such younger fission-track ages. These fluids were also responsible for the deposition of the $\mathrm{Pb}$ $\mathrm{Zn} \mathrm{Cu}$ mineralization that is found in TSZ mylonites.

Acknowledgements Paul Andriessen, Barbara Ventura, Sarah Shoemaker, and K. Hammerschmidt are thanked for their comments on a previous version of the manuscript. This work is in cluded in the objectives and partially supported by the Plan Andaluz de Investigación of the Junta de Andalucia RNM 326 and by the CICYT projects BTE2002-04168-CO3-02 and BTE20000575 of the Ministerio de Ciencia y Tecnología.

\section{References}

Anderweg B (2002) Cenozoic tectonic evolution of the Iberian Peninsula, causes and effects of changing the stress field. $\mathrm{PhD}$ Thesis, VU Amsterdam, p 170

Anderweg B, De Vicente G, Cloetingh S, Giner J, Muñoz Martín A (1999) Local stress fields and intraplate deformation of Iberia: variations in spatial and temporal interplay of regional stress sources. Tectonophysics 305:153 164

Andonaegui P (1990) Geoquímica y geocronología de los granitoides del sur de Toledo. PhD Thesis, Universidad Complutense Madrid, p 365

Aparicio A, Grachev A, Drubetskoy E, Novitsky I (1990) Dataciones $\mathrm{K} / \mathrm{Ar}$ en la unidad magmática de Toledo. Boletín Geológico y Minero 101 103:468 472

Barbarand J, Carter A, Word IG, Hurford AJ (2003) Compositional and structural control of fission track annealing in apatite. Chem Geol 198:107 137
Barbero L (1992) Plutonismo sinorogénico en un área granulítica hercínica: El Complejo Anatéctico de Toledo. PhD Thesis, Universidad Complutense de Madrid, p 450

Barbero L (1995) Granulite-facies metamorphism in the anatectic complex of Toledo, Spain: late hercynian tectonic evolution by crustal extension. J Geol Soc Lond 152:365 382

Barbero L (2004) Cooling paths in the Montes de Toledo area. Boletín Sociedad Española de Mineralogía (in press)

Barbero L, Rogers G (1999) Implications of U-Pb monazite ages from syn-orogenic granites of the Anatectic Complex of Toledo (Spain) in the evolution of the central part of the hercynian Iberian belt. Document du BRGM 290:203

Barbero L, López Garrido AC, García-Hernández M, Quesada S, Martínez del Olmo W (2001) Evolución termal mesozoica de la Cuenca Prebética (Sierra de Segura) inferida mediante análisis de huellas de fisión en apatito: resultados preliminares. Geotemas 3(2): 155160

Barbero L, López Garrido AC, García Hernández M, Quesada S (2002) Thermal history of the prebetic platform: constraints from apatite fission track data. Geotemas 4:23 26

Burtner RL, Nigrini A, Donelick RA (1994) Thermochronology of lower cretaceaous source rocks in the Idaho-Wyoming thrust belt. AAPG Bull 78:1613 1636

Cloetingh S, Burov E, Beekman F, Anderweg B, Andriessen PAM, García Castellanos, D, de Vicente G, Vegas R (2002) Lithosphere folding in Iberia. Tectonics 21:1041 1066

De Bruijne $\mathrm{CH}$ (2001) Denudation, intraplate tectonics and far field effects: an integrated apatite fission track study in central Spain. PhD Thesis, VU Amstermdam, p 164

De Brujne CH, Andriessen PAM (2002) Far field effects of Alpine plate tectonism in the Iberian microplate recorded by faultrelated denudation in the Spanish central system. Tectonophysics 349:161 184

De Bruijne $\mathrm{CH}$, Andriessen PAM (2000) Interplay of intraplate tectonics and surface processes in the Sierra de Guadarrama (Central Spain) assessed by apatite fission track analysis. Phys Chem Earth 25:555 565

Dercourt J, Gaetani M, Vrielynck B et al (eds) (2000) Atlas PeriTethys, paleogeographical maps. CCGM/CGMV, Paris

Donelick RA (1993) Apatite etching characteristics versus chemical composition. Nucl Tracks Rad Meas 21:604

Donelick RA, Ketcham RA, Carlson WD (1999) Variability of apatite fission-track annealing kinetics II: crystallographic orientation effects. Am Miner 84:1224 1234

Dunn AM, Reynolds PH, Clarke B, Ugidos JM (1998) A comparison of the age and composition of the Shelbourne dyke, Nova Scotia, and the Messejana dyke, Spain. Can J Earth Sci 35:1110 1115

Galbraith RF (2002) Some remarks on fission-track observational biases and crystallographic orientation effects. Am Miner 87:991 995

Galbraith RF, Laslett GM (1988) Some calculations relevant to thermal annealing of fission tracks in apatite. Proc R Soc Lond A 419:305 321

Gallagher K (1995) Evolving temperature histories from apatite fission-track data. Earth Planet Sci Lett 136:421 435

Giménez R, Martín-Chivelet J, Vilas L (1993) Upper Albian to Middle Cenomanian carbonate platforms of the Betic and Iberian basins (Spain). In: Simó J AT, Scott RW, Masse JP(eds) Cretaceous carbonate platforms, vol 56. AAPG Memoires, pp 271281

Gleadow AJW, Duddy IR, Green PF, Lovering JF (1986) Confined fission track lengths in apatite. A diagnostic tool for thermal history analysis. Contrib Miner Petrol 94:405 415

Gräfe K-U, Wiedemann J (1993) Sequence stratigraphy in the Upper Cretaceous of the Basco-Cantabrian Basin (northern Spain). Geol Rundschau 82:327 361

Green PF, Durrani SA (1977) Annealing studies of tracks in crystals. Nucl Track Detect 1:33 39

Green PF, Duddy IR, Gleadow AJW, Tingate PR, Laslett GM (1985) Fission track annealing: track length measurements and the form of the Arrhenius plot. Nucl Track 10:323 328 
Green PF, Duddy IR, Gleadow AJW, Tingate PR, Laslett GM (1986) Thermal annealing of fission tracks in apatite, 1. A quantitative description. Chem Geol 59:237 253

Hernández Enrile JL (1991) Extensional tectonics of the Toledo ductile-brittle shear zone, central Iberian Massif. Tectonophysics 191:311 324

Hurford AJ, Green PF (1983) The zeta age calibration of fissiontrack dating. Isotope Geosci 1:285 317

Ketcham RA (2003) Observations on the relationship between crystallographic orientation and biasing in apatite fission-track measurements. Am Miner 88:817 829

Ketcham RA, Donelick RA, Donelick MB (2000) AFTSolve: a program for multi-kinetic modeling of apatite fission-track data. Geol Mater Res 2:1 32

Laslett GM, Green PF, Duddy IR, Gleadow AJW (1987) Thermal annealing of fission track in apatite, 2 . A quantitative analysis. Chem Geol 65:1 13

López García JA, Villaseca C, Barbero L (2003) Estudio preliminar de las mineralizaciones de $\mathrm{Pb} \mathrm{Zn}$ de Mazarambroz, banda milonítica de Toledo. Boletín Soc Esp Min 26(A):171 172

Mancktelow NS, Grasemann B (1997) Time-dependent effect of heat advection and topography on cooling histories during erosion. Tectonophysics 270:167 195

Martín-Chivelet J (1997) Late Cretaceous subsidence history of the Betic Continental Margin (Jumilla-Yecla region, SE Spain). Tectonophysics 265:191 211

Parrish R (1990) Cooling rates from $700=C 400=C$ in high grade rocks: applications of $\mathrm{U} / \mathrm{Pb}$ geochronometry. Goldschmidt Conf Abstr

Reicherter KR, Pletsch TK (2000) Evidence of a synchronous circum-Iberian subsidence event and its relation to the AfricanIberian plate convergence in the Late Cretaceous. Terra Nova $12: 141 \quad 147$

Ring U, Brandon MT, Willett SD, Lister GS (1999) Exhumation processes. In: Ring U, Brandon MT, Lister GS, Willett SD (eds) Exhumation processes: normal faulting, ductile flow and erosion. Geol Soc Special Publ 154:1 27

Sánchez Carretero R, Contreras E, Martín Parra LM, Martínez Salanova J, Gutiérrez Alonso G, Barbero L (2004) Mapa Geológico de España E 1:50.000 Hoja 657 (Sonseca). Instituto Geológico y Minero de España (in press)

Santa Teresa I, Carbó A, Capote R, Casquet C (1983) Geometría y profundidad del granito de Orgaz en base a datos gravimétricos. Studia Geológica Salmanticensia XVIII:237 260

Schermerhorn LJG, Priem HNA, Boelrijk NAI, Hebeda EH, Verdumen EAT, Verscluse RH (1978) Age and origin of the Messejana dolerite fault dyke system (Portugal and Spain) in the light of the North Atlantic Ocean. J Geol 86:229 309
Schwentke W, Kuhnt W (1992) Subsidence history and continental margin evolution of the western Pyrenean and Basque basins. Palaeogeogr Paleaeoclimatol Palaeoecol 95:297 318

Sopeña A, Virgili C, Arche A, Ramos A, Hernando S (1983) El Triásico. In: Libro Jubilar J. M. Ríos, Geología de España. Inst Geol Miner España 2:47 62

Sosson M, Morillon AC, Bourgois J, Féraud G, Poupeau G, SaintMarc P (1998) Late exhumation stages of the Alpujarride Complex (western Betic Cordilleras, Spain): new thermochronological and structural data on Los Reales and Ojén nappes. Tectonophysics 285:253 273

Stapel G, Cloetingh S, Pronk B (1996) Quantitative subsidence analysis of the Mesozoic evolution of the Lusitanian basin. Tectonophysics 266:493 507

Vera JA (2001) Evolution of the South Iberian Continental Margin. In: Ziegler PA, Cavazza W, Robertson AHF, CraquinSoleau S (eds) Peri-Tethys Memoir 6: Peri-Tethyan Rift/ Wrench Basins and Passive Margins. Mémoires du Muséum national d'Histoire naturelle 186:109 143

de Vicente G, Giner JL, Muñoz Martín A, González-Casado JM Lindo R (1996) Determination of present-day stress tensor and neotectonic interval in the Spanish central system and Madrid basin, central Spain. Tectonophysics 266:405 424

Villaseca C, Nuez J (1986) Diques camptoníticos en el Sistema Central Español. Est Geol 42:69 77

Villaseca C, Huertas MJ, Nuez J (1992) Magmatismo postorogénico y anorogénico en el Sistema Central Español. Geogaceta $11: 3437$

Villaseca C, Downes H, Pin C, Barbero L (1999) Nature and composition of the lower continental crust in Central Spain: inferences from granulitic xenoliths and implications on the granulite-granite linkage. J Petrol 40:1465 1496

Virgili C, Sopeña A, Ramos A, Arche A, Hernando S (1983) El relleno posthercínico y el comienzo de la sedimentación Mesozoica. In: Libro Jubilar J. M. Ríos, Geología de España. Inst Geol Miner España 2:25 36

Wagner $G$, van den Haute P (1992) Fission track dating. Kluwer, Dordrecht p 285

Wygrala (1989) Integrated study of an oil field in the southern Po Basin, Northern Italy. Reports of the Forschungszentrum Jülich Jül-2313. Jülich, Germany, p 217

Ziegler PA (1990) Geological Atlas of Western and Central Europe. Shell Internationale Petroleoum Maatsschappij, p 239

Ziegler PA, Cloetingh S, van Wees J-D (1995) Dynamics of intraplate compressional deformation: the Alpine foreland and other examples. Tectonophysics 252:7 59

Zoback ML (1992) First- and second-order patterns of stress in the lithosphere: the world stress map project. J Geophys Res 97:11703 11728 